\title{
Lipoid proteinosis: different clinical features in two siblings
}

\author{
Lipoproteinoza - odmienne obrazy kliniczne choroby u rodzeństwa
}

\author{
Katarzyna Łuczak', Elżbieta Wojtowicz-Prus', Robert Śmigiel ${ }^{2}$, Katarzyna Wertheim-Tysarowska ${ }^{3}$, \\ Sylwia Radomska³, Jacek Podolski ${ }^{4}$, Jolanta Węgłowska'
}

\author{
'Department of Dermatology with Pediatric Dermatology Unit, Provincial Specialist Hospital, Wroclaw, Poland \\ 2Department of Propaeudetics of Pediatrics and Rare Diseases, Chair of Pediatrics, Medical University of Wroclaw, Poland \\ ${ }^{3}$ Department of Medical Genetics, Institute of Mother and Child, Warsaw, Poland \\ ${ }^{4} \mathrm{NZOZ}$ Meditest, Szczecin, Poland \\ 'Oddział Dermatologiczny z Pododdziałem Dermatologii Dziecięcej, Wojewódzki Szpital Specjalistyczny, Wrocław, Polska \\ ${ }^{2}$ Zakład Propedeutyki Pediatrii i Chorób Rzadkich, Katedra Pediatrii, Uniwersytet Medyczny, Wrocław, Polska \\ ${ }^{3}$ Zakład Genetyki Medycznej, Instytut Matki i Dziecka, Warszawa, Polska \\ ${ }^{4} \mathrm{NZOZ}$ Meditest, Szczecin, Polska
}

\author{
CORRESPONDING AUTHOR/ \\ ADRES DO KORESPONDENCJI: \\ Katarzyna Łuczak \\ Oddział Dermatologiczny \\ z Pododdziałem \\ Dermatologii Dziecięcej \\ Wojewódzki Szpital \\ Specjalistyczny \\ ul. Kamińskiego 73 a \\ 51-124 Wrocław, Polska \\ tel.: +48664780 266 \\ e-mail: luczak.kas@gmail.com
}

\begin{abstract}
Introduction. Lipoid proteinosis is a rare autosomal recessive disease caused by mutations in the extracellular matrix protein 1 gene (ECM1). Abnormal function of ECM1 protein leads to accumulation of hyaline material in tissues.

Objective. To present a case of a 6-year-old patient and his 4-year-old sister with different clinical features of lipoid proteinosis.

Case report. A six-year-old boy with chronic hoarseness presented to the Dermatology Department because of polymorphic cutaneous lesions: erythema, erosions, crusts, atrophic scars, foci of hypopigmentation and hyperpigmentation. Histological examination of the skin revealed hyaline deposits. The patient's younger sister presented with beaded papules on the margin of the eyelids and chronic hoarseness. A genetic test revealed that ECM1 was compound heterozygous in both siblings.
\end{abstract}

Conclusion. One type of ECM1 gene mutation can determine various clinical manifestations of lipoid proteinosis.

\section{STRESZCZENIE}

Wprowadzenie. Lipoproteinoza jest rzadką chorobą dziedziczoną autosomalnie recesywnie, związaną z gromadzeniem się złogów hialiny w tkankach wskutek mutacji w genie kodującym białko 1 macierzy zewnątrzkomórkowej (ECM1).

Cel pracy. Przedstawienie przypadku 6-letniego pacjenta oraz jego 4-letniej siostry, u których stwierdzono objawy lipoproteinozy o różnym nasileniu.

Opis przypadku. Sześcioletni chłopiec z przewlekłą chrypką został przyjęty do oddziału dermatologicznego z powodu polimorficznych zmian skórnych: rumieni, nadżerek, strupów, blizn zanikowych, ognisk odbarwień i przebarwień, zlokalizowanych głównie na szyi, w okolicy pach, zgięć łokciowych i podkolanowych. W badaniu histopatologicznym skóry stwierdzono złogi hialiny. U młodszej siostry pa- 
cjenta obecne były linijnie układające się grudki na brzegach powiek oraz przewlekła chrypka. W badaniu genetycznym wykazano złożone heterozygotyczne mutacje genu ECM1 u obojga rodzeństwa.

Wniosek. Jednakowe mutacje genu ECM1 mogą determinować wystąpienie różnych obrazów klinicznych lipoproteinozy.

Key words: lipoid proteinosis, hialinosis cutis et mucosae, Urbach-Wiethe disease.

Słowa kluczowe: lipoproteinoza, hialinosis cutis et mucosae, choroba Urbacha-Wiethego.

\section{INTRODUCTION}

Lipoid proteinosis (Urbach-Wiethe disease, lipoidosis cutis et mucosae or hyalinosis cutis et mucosae) is a rare autosomal recessive genodermatosis caused by various mutations in the gene encoding extracellular matrix protein 1, mapped to a locus on chromosome $1 q 21[1,2]$. The precise function of extracellular matrix protein 1 is not known. However, as extracellular matrix protein 1 gene (ECM1) is capable of binding other proteins it has been shown to have an important role in structural organization of the dermis [1]. It also participates in keratinocyte differentiation, regulation of basement membrane integrity and angiogenesis [2-4]. The loss of function of ECM1 leads to the deposition of a hyaline material in the skin, mucous membranes and internal organs and is a direct cause of clinical manifestations of lipoid proteinosis $[2,5]$. The exact pathogenesis of this phenomenon is still unknown.

\section{OBJECTIVE}

The purpose of this paper is to report on a 6-yearold boy and his 4-year-old sister with different degrees of clinical manifestations of lipoid proteinosis.

\section{CASE REPORT}

A 6-year-old boy, presenting with hoarseness since early infancy, was admitted to the Dermatology Ward for evaluation of polymorphic skin lesions. The first dermatologic symptoms which manifested as rounded ulceration of the third finger of the right hand along with erythematous papules and plaques were noted at 8 months of age. Over time, cutaneous eruptions continued to develop predominantly as a result of minor mechanical trauma.

Physical examination revealed thickened and waxy skin, along with widespread erythematous lesions, erosions, atrophic scars, discoloration and

\section{WPROWADZENIE}

Lipoid proteinosis (choroba Urbacha-Wiethego, lipoproteinoza, hialinosis cutis et mucosae) jest rzadką chorobą genetyczną, dziedziczoną autosomalnie recesywnie, której przyczyną są różnego typu mutacje genu kodującego białko 1 macierzy zewnątrzkomórkowej (extracellular matrix protein 1 - ECM1), zlokalizowanego w locus 1q21 [1, 2]. Funkcja białka 1 macierzy zewnątrzkomórkowej nie jest do końca poznana. Wiadomo, że dzięki zdolności do wiązania innych protein białko ECM1 odgrywa ważną rolę w organizacji prawidłowej struktury skóry właściwej [1]. Ponadto bierze udział w procesie różnicowania keratynocytów, regulacji integralności błony podstawnej, a także w regulacji angiogenezy [2-4]. Nieadekwatna funkcja białka ECM1 sprzyja gromadzeniu się złogów hialiny w skórze, błonach śluzowych i narządach wewnętrznych, co jest bezpośrednią przyczyną objawów klinicznych lipoproteiozy [2,5]. Patomechanizm tego zjawiska nie został dotąd dokładnie poznany.

\section{CEL PRACY}

Przedstawienie przypadku 6-letniego pacjenta oraz jego 4-letniej siostry, u których stwierdzono objawy lipoproteinozy o różnym nasileniu.

\section{OPIS PRZYPADKU}

Sześcioletni chłopiec z chrypką od okresu noworodkowego został przyjęty do oddziału dermatologicznego w celu diagnostyki polimorficznych zmian skórnych. Pierwsze objawy dermatologiczne w postaci okrągłego owrzodzenia palca III ręki prawej oraz grudek i blaszek rumieniowych odnotowano w 8. miesiącu życia dziecka. W kolejnych latach na skórze chłopca pojawiały się kolejne wykwity, najczęściej wskutek drobnych urazów mechanicznych.

W badaniu fizykalnym stwierdzono pogrubienie i woskowatość skóry, rozległe zmiany rumieniowe, 
hyperpigmentation, located mainly on the neck, in the region of the axillae, elbow and popliteal flexures and sacral area. On the mucous membrane of the lower lip pale yellow infiltration and oedema were observed. Laboratory studies revealed values within normal limits. Chest X-ray and abdominal ultrasound did not reveal any abnormality. Laryngological evaluation with endoscopy of the nose, pharynx and larynx was performed. The structure and macroscopic appearance of the larynx were found to be normal. A skin biopsy was performed for histological verification. It confirmed clearly the deposition of PASpositive homogeneous hyaline material, mainly in the upper layers of the dermis and around blood vessels and sweat glands (figs. 1-6).

The patient's 4-year-old sister presented with hoarseness since early infancy and non-inflammatory beaded papules along the eyelid margins referred to as moniliform blepharosis.

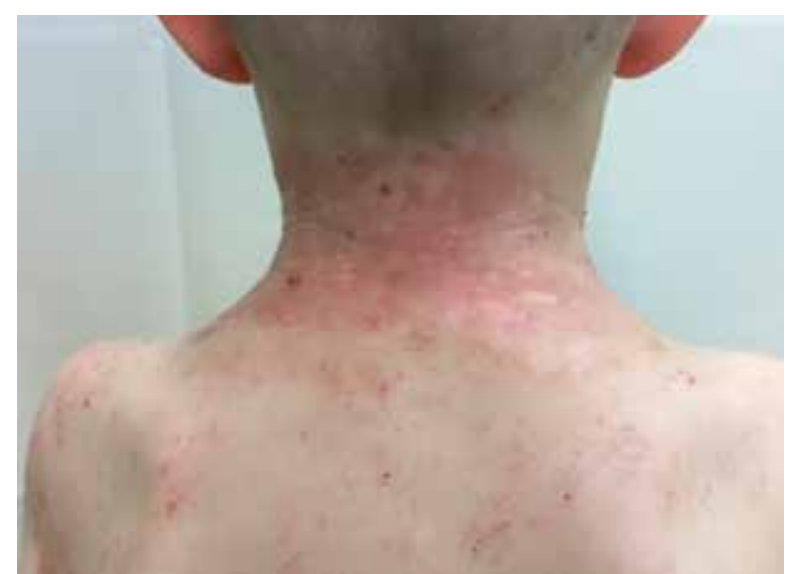

Figure I. The patient's neck and upper back

Rycina I. Zmiany skórne na szyi i plecach pacjenta

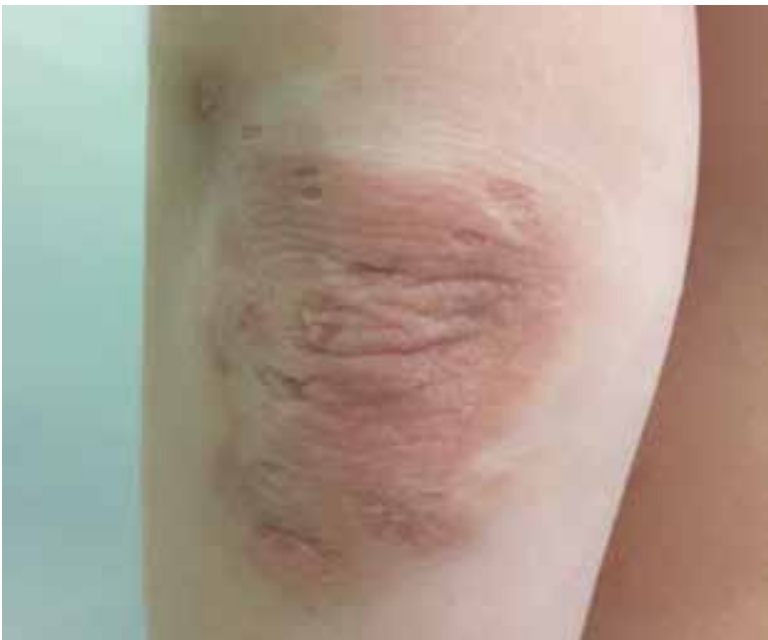

Figure 3. The patient's elbow

Rycina 3. Zmiany skórne na łokciu pacjenta nadżerki, strupy, blizny zanikowe oraz przebarwienia i odbarwienia, zlokalizowane głównie na szyi, w okolicy dołów pachowych, zgięć łokciowych i kolanowych oraz okolicy krzyżowej. Na błonie śluzowej wargi dolnej zaobserwowano bladożółte nacieki i obrzęk. W wynikach badań laboratoryjnych nie wykazano istotnych odchyleń od wartości referencyjnych. $\mathrm{W}$ badaniu rentgenograficznym klatki piersiowej i ultrasonograficznym brzucha również nie stwierdzono nieprawidłowości. Przeprowadzono badanie laryngologiczne z endoskopią nosa, gardła i krtani. Budowa i makroskopowy obraz krtani były prawidłowe. Pobrano wycinek chorobowo zmienionej skóry do oceny histologicznej. W barwieniu PAS wykazano wyraźne gromadzenie się homogennego materiału hialinowego, głównie w górnych warstwach skóry właściwej oraz wokół naczyń i gruczołów potowych (ryc. 1-6).

U 4-letniej siostry pacjenta stwierdzono chrypkę od okresu noworodkowego oraz obecność niezapal-

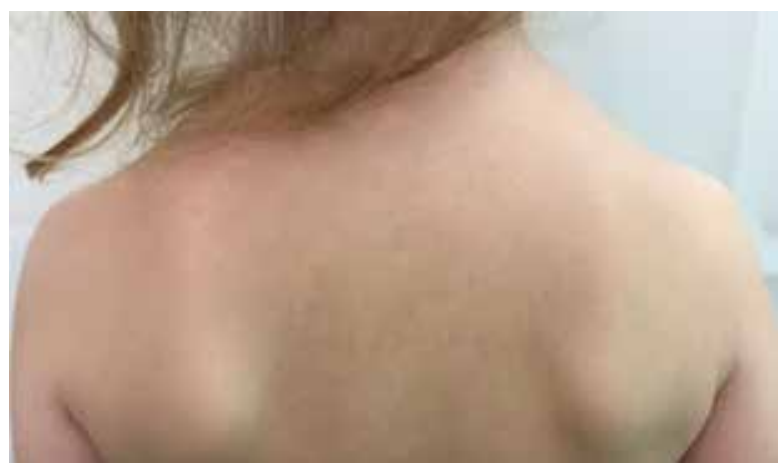

Figure 2. Normal skin of the patient's sister Rycina 2. Prawidłowa skóra siostry pacjenta

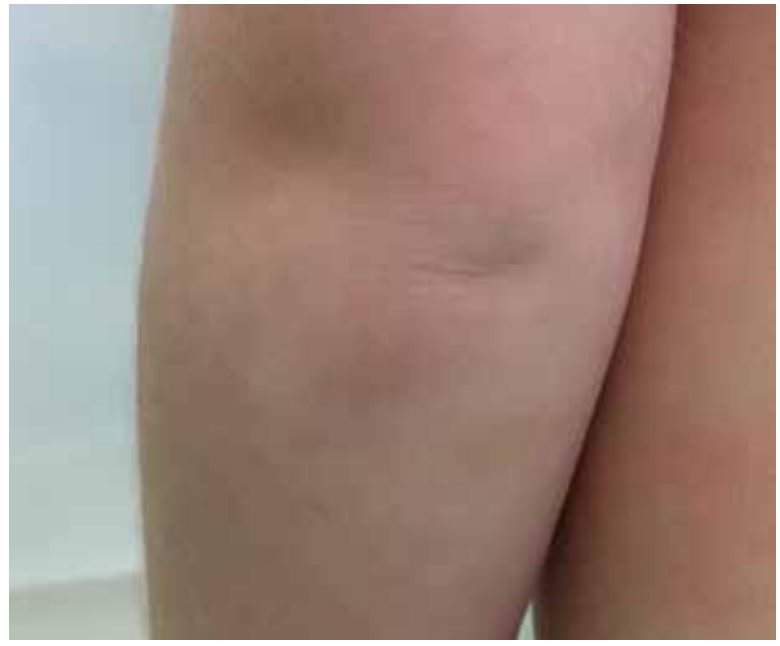

Figure 4. Normal skin of the patient's sister

Rycina 4. Prawidłowa skóra siostry pacjenta 


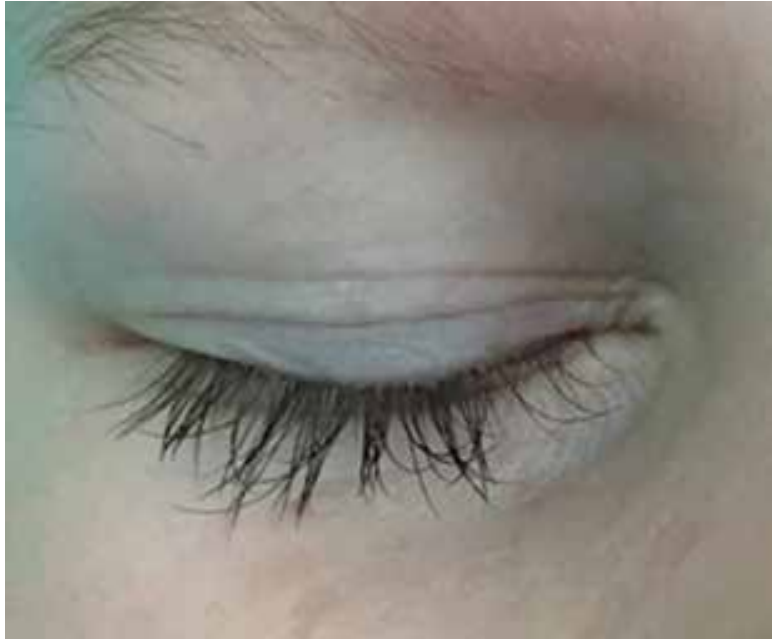

Figure 5. The patient's eyelid with no papule

Rycina 5. Prawidłowa skóra powieki pacjenta

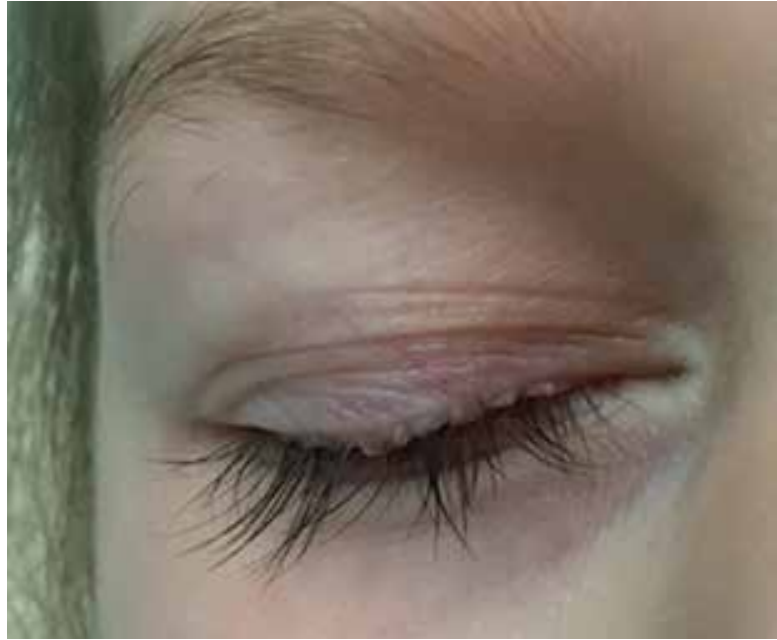

Figure 6. Beaded papules on the patient's sister's eyelid

Rycina 6. Grudki na brzegu powieki siostry pacjenta (objaw sznura peref)
A

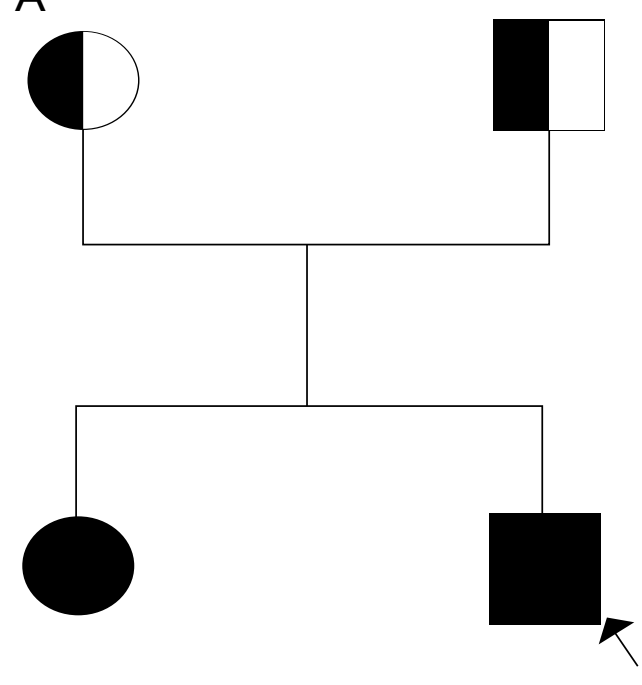

B
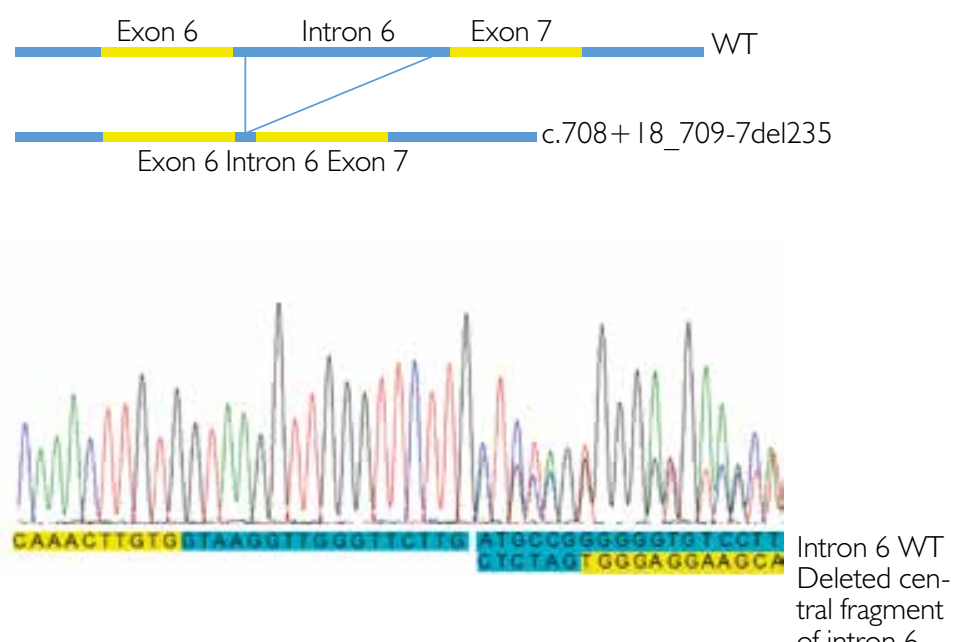

Figure 7. A - Family tree with proband indicated by an arrow. B - Upper panel: schematic representation of wt allele and allele with central fragment deletion in intron 6. Lower panel: fragment of proband's fluorogram showing deletion of central fragment of intron 6 in one allele. In both panels exons are marked in yellow and introns in blue

Rycina 7. A - Rodowód rodziny. Strzałką oznaczono probanda. B - Górna ilustracja: schemat przedstawiający allel WT oraz allel z delacją centralnego fragmentu w intronie 6. Dolna ilustracja: fragment fluorogramu probanda ukazujący delecję centralnego fragmentu intronu 6 w jednym allelu. Na obu ilustracjach egzony są zaznaczone na żółto, a introny na niebiesko

In order to obtain molecular confirmation of the diagnosis of Urbach-Wiethe disease, both children underwent genetic testing based on Sanger sequencing. All encoding parts of the ECM1 gene were assessed as well as the exon-intron junctions. In the boy's genetic material a nonsense mutation was identified. It resulted from transversion of cytosine to guanine (c.1464C $>\mathrm{G}$ ) in one allele in the analysed nych grudek wzdłuż brzegów powiek (tzw. moniliform blepharosis).

W celu molekularnej weryfikacji rozpoznania choroby Urbacha-Wiethego przeprowadzono badanie genetyczne obojga dzieci oparte na sekwencjonowaniu metodą Sangera. Ocenie poddano wszystkie fragmenty kodujące gen ECM1, a także złącza ekson-intron. W materiale genetycznym chłopca zidentyfikowano mutacje 
gene and variant c.708+18_709-del235, i.e. intraintron deletion of 235 nucleotides with retention of the exon-intron junction in exon 6 and intron 6 along with exon 7 in the second allele. Identical mutation of the ECM1 gene was identified in the patient's sister (fig. 7).

The parents were not related; nevertheless, in this case, it is not relevant due to two different mutations in two alleles of ECM1.

The patient is being treated with topical antiseptics and emollients. After therapy, reduced skin susceptibility to injuries was observed.

\section{DISCUSSION}

Lipoid proteinosis is a rare autosomal recessive genodermatosis characterized by accumulation of hyaline deposits in tissues, caused by mutations in the gene encoding extracellular matrix protein 1 (ECM1).

Clinical findings may vary among affected individuals and depend on the location and degree of hyaline infiltration. Patients present with thickened and waxy skin, increased susceptibility to minor trauma and impaired wound healing manifested by formation of blisters, papules, erosions, ulcerations, crusts and pock-like atrophic scars [5]. The development of non-inflammatory papules, known as moniliform blepharosis, which may be present along the margins of both eyelids, is regarded to be a pathognomonic sign of lipoid proteinosis [6,7]. Other findings that have been reported in the course of this disease include alopecia and nail dystrophy $[5,8]$.

Accumulation of the hyaline deposits in oral mucosa may lead to induration and thickening of the lips, gingiva, palate and the sub-lingual frenulum, as well as xerostomia and reduced tongue movement resulting in dysphagia and difficulty speaking $[9,10]$. Hoarseness, a hoarse cry or even inability to produce voice are characteristic features of lipoid proteinosis with vocal cord involvement [11].

Deposition of hyaline-like material in the upper respiratory tract may lead to respiratory difficulty and recurrent infections. Involvement of the central nervous system in Urbach-Wiethe disease is manifested by seizures, headaches, psychotic symptoms, memory impairment and behavioural disturbances [12]. Accumulation of hyaline in the gastrointestinal tract most likely does not present with clinical manifestations [13].

To date, more than 40 mutations in the ECM1 gene in patients with lipoid proteinosis, located mostly within exons 6 or 7, have been reported [14-16]. In the past, it was hypothesized that there is a correlation between the severity of the symptoms and the location of the mutation [15]. This hypothesis was discarded in 2007 [1, 14].

In the case of presented siblings, genetic testing revealed transversion of cytosine to guanine in one allele nonsensowną, powstałą wskutek transwersji cytozyny na guaninę (c.1464C>G), w jednym allelu badanego genu oraz wariant c.708+18_709-7del235, tj. wewnątrzintronową delecję 235 nukleotydów z zachowaniem złączy ekson-intron dla eksonu 6 i intronu 6 oraz intronu 6 i eksonu $7 \mathrm{w}$ drugim allelu. U siostry pacjenta stwierdzono identyczne mutacje genu ECM1 (ryc. 7).

Na podstawie wywiadu wykluczono pokrewieństwo rodziców, jednak w tym przypadku fakt ten nie ma znaczenia, gdyż w allelach genu ECM1 u dzieci wystąpiły dwie różne mutacje - inna w allelu pochodzenia matczynego i inna w allelu pochodzenia ojcowskiego.

W terapii u chłopca zastosowano miejscowe środki odkażające oraz emolienty i uzyskano niewielką poprawę w zakresie zmniejszenia podatności skóry na drobne urazy mechaniczne.

\section{OMÓWIENIE}

Lipoid proteinosis jest rzadką chorobą dziedziczoną autosomalnie recesywnie, związaną z gromadzeniem się złogów hialiny w tkankach wskutek mutacji w genie kodującym białko 1 macierzy zewnątrzkomórkowej (ECM1).

Obraz kliniczny lipoproteinozy może być różny u poszczególnych pacjentów w zależności od nasilenia oraz umiejscowienia nacieków hialinowych. U chorych stwierdza się pogrubienie i woskowatość skóry, zwiększoną wrażliwość na urazy mechaniczne oraz nieprawidłowe gojenie się ran objawiające się powstawaniem pęcherzy, grudek, nadżerek, owrzodzeń, strupów i ospopodobnych blizn zanikowych [5]. Rozwój niezapalnych grudek wzdłuż brzegów powiek (tzw. moniliform blepharosis) jest uznawany za objaw patognomoniczny lipoproteinozy $[6,7]$. Opisywano przypadki łysienia i dystrofii paznokci w przebiegu tej choroby $[5,8]$.

Gromadzenie się złogów hialiny na błonach śluzowych jamy ustnej może powodować m.in. stwardnienie i przerost błony śluzowej warg, policzków, dziąseł, podniebienia, wędzidełka podjęzykowego, a także kserostomię i obniżoną ruchomość języka skutkującą zaburzeniami połykania i trudnościami w mówieniu $[9,10]$. Chrypka, "zachrypnięty" płacz, a nawet brak możliwości wydobycia głosu są objawem lipoproteinozy z zajęciem strun głosowych [11].

Hialinopodobne złogi gromadzą się również w tkankach górnych dróg oddechowych, co może powodować trudności w oddychaniu i nawracające infekcje. W przebiegu choroby Urbacha-Wiethego opisywano także objawy dysfunkcji ośrodkowego układu nerwowego, takie jak napady drgawkowe, bóle głowy, objawy wytwórcze, zaburzenia pamięci i zachowania [12]. Gromadzenie się złogów hialiny w przewodzie pokarmowym najprawdopodobniej nie wywołuje objawów klinicznych [13].

Dotychczas u pacjentów z rozpoznaną lipoproteinozą opisano ponad 40 mutacji genu ECM1, występujących najczęściej w eksonach 6 i 7 [14-16]. W przeszłości podej- 
of the ECM1 gene and deletion of 235 nucleotides in the second allele. The first of the above-mentioned mutations due to the nature of the molecular defect, e.g. introduction of a premature termination codon, can be regarded as a pathogenic mutation with a probability approaching certainty. As a result of the mutation identified in the second allele of the discussed gene, ECM1 transcript processing may be impaired. However, in order to confirm this fact further molecular analysis based on mRNA testing is needed. As lipoid proteinosis is inherited in an autosomal recessive manner only confirmation of the mutation pathogenicity in both alleles allows definitive molecular confirmation of the clinical diagnosis. Nevertheless, the presented case of siblings with Urbach-Wiethe disease confirms the lack of any close genotype-phenotype correlation in this rare genodermatosis.

Currently, there is no known effective treatment of lipoid proteinosis. Therapeutic interventions documented in the literature such as treatment with dimethyl sulphoxide [17], D-penicillamine [18] and acitretin [19-21] have shown moderate success in reducing the severity of some symptoms of lipoid proteinosis and in halting the progression of the disease. Laser ablation may temporarily improve the skin condition of affected individuals and relieve hoarseness [22, 23].

Although lipoid proteinosis undoubtedly may decrease patients' quality of life its course is usually benign and does not affect patients' life expectancy [3].

\section{CONCLUSIONS}

The discussed case of siblings with lipoid proteinosis confirms that there is no genotype-phenotype correlation in this rare disease. Identical mutations of the ECM1 gene may determine different clinical manifestations of lipoid proteinosis.

Systemic therapy interventions that have been attempted so far achieved limited success. Treatment of this disease is controversial and should be established only in selected cases following careful consideration of the potential benefits and the risk of complications.

As the clinical manifestations of lipoid proteinosis may vary considerably it is of interest not only to dermatologists but also dentists, laryngologists, ophthalmologists and neurologists.

\section{CONFLICT OF INTEREST}

The authors declare no conflict of interest. rzewano istnienie korelacji między nasileniem objawów choroby a miejscem wystąpienia mutacji [15]. Hipoteza ta została odrzucona w 2007 roku [1, 14].

U przedstawionego rodzeństwa badanie genetyczne wykazało transwersję cytozyny na guaninę w jednym allelu genu ECM1 oraz delecję 235 nukleotydów w drugim allelu. Pierwszą z wymienionych mutacji ze względu na rodzaj defektu molekularnego - wprowadzenie przedwczesnego kodonu STOP - można z prawdopodobieństwem graniczącym z pewnością zaliczyć do mutacji patogennych. Wskutek mutacji zidentyfikowanej w drugim allelu omawianego genu możliwe jest zaburzenie procesu transkrypcji ECM1, jednak aby ten fakt potwierdzić, należy wykonać dalsze analizy molekularne oparte na badaniach mRNA. Z powodu autosomalnie recesywnego sposobu dziedziczenia lipoproteinozy jedynie potwierdzenie statusu patogenności mutacji w obu allelach umożliwia ostateczną weryfikację molekularną rozpoznania klinicznego. Niemniej prezentowany przypadek rodzeństwa z chorobą Urbacha-Wiethego potwierdza brak ścisłej korelacji między genotypem i fenotypem $w$ tej rzadko występującej genodermatozie.

Obecnie nie jest znana skuteczna metoda leczenia. Opisywano próby zastosowania w terapii dimetylosulfotlenku [17], D-penicylaminy [18] i acytretyny [19-21], z umiarkowanie dobrym efektem $\mathrm{w}$ postaci zmniejszenia nasilenia niektórych objawów lipoproteinozy i zatrzymania postępu choroby. Zabiegi z wykorzystaniem laserów ablacyjnych mogą doraźnie poprawiać stan skóry pacjentów i zmniejszać nasilenie chrypki [22, 23].

Lipoid proteinosis niewątpliwie może obniżać jakość życia pacjentów, jednak zazwyczaj ma łagodny przebieg i nie wpływa na długość życia [3].

\section{WNIOSKI}

Przedstawiony przypadek rodzeństwa z lipoid proteinosis potwierdza brak korelacji między genotypem i fenotypem w tej rzadko występującej jednostce chorobowej. Jednakowe mutacje genu ECM1 mogą determinować wystąpienie różnych obrazów klinicznych lipoproteinozy.

Podejmowane dotychczas próby terapii ogólnej charakteryzują się umiarkowaną skutecznością. Leczenie tej choroby jest kontrowersyjne i powinno być podejmowane jedynie $\mathrm{w}$ wybranych przypadkach, po rozważnej ocenie stosunku potencjalnych korzyści do ryzyka wystąpienia działań niepożądanych.

Ze względu na różnorodność objawów omawiana jednostka chorobowa jest przedmiotem zainteresowania nie tylko dermatologów, lecz także stomatologów, laryngologów, okulistów i neurologów.

\section{KONFLIKT INTERESÓW}

Autorzy nie zgłaszają konfliktu interesów. 


\section{References}

\section{Piśmiennictwo}

1. Chan I., Liu L., Hamada T., Sethuraman G., McGrath J.A.: The molecular basis of lipoid proteinosis: mutations in extracellular matrix protein 1. Exp Dermatol 2007, 16, 881-890.

2. Hamada T., McLean W.H., Ramsay M., Ashton G.H., Nanda A., Jenkins T., et al.: Lipoid proteinosis maps to 1q21 and is caused by mutations in the extracellular matrix protein 1 gene (ECM1). Hum Mol Genet 2002, 11, 833-840.

3. Mittal H.C., Yadav S., Malik S., Singh G.: Lipoid proteinosis. Int J Clin Pediatr Dent 2016, 9, 149-151.

4. Kowalewski C., Kozłowska A., Chan I., Górska M., Woźniak K., Jabłońska S., et al.: Three-dimensional imaging reveals major changes in skin microvasculature in lipoid proteinosis and lichen sclerosus. J Dermatol Sci 2005, 38, 215-224.

5. Hamada T.: Lipoid proteinosis. Clin Exp Dermatol 2002, 27, 624-629.

6. Kamath S.J., Marthala H., Manapragada B.: Ocular manifestations in lipoid proteinosis: a rare clinical entity. Indian J Ophthalmol 2015, 63, 793-795.

7. Belliveau M.J, Alkhotani A., Ali A.: Moniliform blepharosis of lipoid proteinosis. JAMA Ophtalmol 2015, 133, e150688.

8. Thaddanee R., Khilnani A.K., Pandya P., Chaturvedi M.: Lipoid proteinosis (Urbach-Wiethe disease) in two siblings. Indian Dermatol Online J 2014, 5 (Suppl 2), S95-S97.

9. Kartal D., Cinar S.L., Kartal L., Saka O.S., Borlu M.: Lipoid proteinosis. Acta Dermatovenerol Alp Pannonica Adriatr 2016, 25, 19-21.

10. Hofer P.A., Bergenholz A.: Oral manifestations in Urbach-Wiethe disease (lipoglycoproteinosis; lipoid proteinosis; hyalinosis cutis et mucosae). Odontol Revy 1975, 26, 39-57.

11. Savage M.M., Crockett D.M., McCabe B.F.: Lipoid proteinosis of the larynx: a cause of voice change in the infant and young child. Int J Pediatr Otorhinolaryngol 1988, 15, 33-38.

12. McGrath J.A.: Lipoid proteinosis. Handb Clin Neurol 2015, 132, 317-322.

13. Custódio Lima J., Nagasako C.K., Montes C.G., Barcelos I.H., de Carvalho R.B., Mesquita M.A.: Gastrointestinal involvement in lipoid proteinosis: a ten-year follow-up of a Brazilian female patient. Case Rep Med 2014, 2014, 952038.

14. Nasir M., Latif A., Ajmal M., Qamar R., Naeem M., Hameed A.: Molecular analysis of lipoid proteinosis: identification of a novel nonsense mutation in the ECM1 gene in a Pakistani family. Diagn Pathol 2011, 6, 69.

15. Hamada T., Wessagowit V., South A.P., Ashton G.H., Oyama N., Siriwattana A., et al.: Extracellular matrix protein 1 gene (ECM1) mutations in lipoid proteinosis and genotype-phenotype correlation. J Invest Dermatol 2003, 120, 345-350.

16. Ludew D., Wertheim-Tysarowska K., Budnik K., Grabarczyk A., Kowalewski C., Karpinska-Mrowiecka M.: Lipoid proteinosis: a first report of mutation Val10Gly in the signal peptide of the ECM1 gene. Adv Dermatol Allergol 2018, 35, 208-211.

17. Wong C.K., Lin C.S.: Remarkable response of lipoid proteinosis to oral dimethyl sulphoxide. Br J Dermatol 1988, 119, 541-544.

18. Kaya T.I., Kokturk A., Tursen U., Ikizoglu G., Polat A.: D-penicillamine treatment for lipoid proteinosis. Pediatr Dermatol 2002, 19, 359-362.

19. Bakry O.A., Samaka R.M., Houla N.S., Basha M.A.: Two Egyptian cases of lipoid proteinosis successfully treated with acitretin. J Dermatol Case Rep 2014, 8, 29-34.

20. Gunduz O., Sahiner N., Atasov P., Senyucel C.: Acitretin treatment for lipoid proteinosis. Case Rep Dermatol Med 2012, $2012,324506$.

21. Luo X.Y., Li Q., Tan Q., Yang H., Xiang J., Miao J.K., et al.: Treatment of lipoid proteinosis with acitretin in two patients from two unrelated Chinese families with novel nonsense mutations of the ECM1 gene. J Dermatol 2016, 43, 804-807.

22. Caliskan E., Acikgoz G., Tunca M., Koc E., Arca E., Akar A.: Treatment of lipoid proteinosis with ablative Er:YAG laser resurfacing. Dermatol Ther 2015, 28, 291-295.

23. Kroukamp G., Lehmann K.: Treatment of laryngeal lipoid proteinosis using CO2 laser. S Afr Med J 2007, 97, 90-92.

Received: 11.02 .2019

Accepted: 11.07 .2019

Otrzymano: 11.02.2019 r

Zaakceptowano: 11.07.2019 r.

How to cite this article

Łuczak K., Wojtowicz-Prus E., Śmigiel R., Wertheim-Tysarowska K., Radomska S., Podolski J., Węgłowska J.: Lipoid proteinosis: different clinical features in two siblings. Dermatol Rev/Przegl Dermatol 2019, 106, 538-544. DOI: https://doi.org/10.5114/dr.2019.90002. 